J Arid Land (2014) 6(6): 762-770

doi: 10.1007/s40333-014-0028-2

jal.xjegi.com; www.springer.com/40333

\title{
Ecophysiological aspects and photosynthetic pathways in 105 plants species in saline and arid environments of Tunisia
}

\author{
Abdallah ATIA ${ }^{1,2^{*}}$, Mokded RABHI ${ }^{2}$, Ahmed DEBEZ ${ }^{2}$, Chedly ABDELLY², Houda GOUIA ${ }^{1}$, \\ Chiraz Chaffei HAOUARI ${ }^{1}$, Abderrazak SMAOUI ${ }^{2}$ \\ ${ }^{1}$ Research Unit, Nutrition and Nitrogen Metabolism and Stress Protein, Department of Biology, Faculty of Sciences of Tunis, \\ Campus Universitaire El Manar I, Tunis 1060, Tunisia; \\ ${ }^{2}$ Laboratory of Extremophile Plants, Centre of Biotechnology of Borj-Cedria, Hammam-Lif 2050, Tunisia
}

\begin{abstract}
In Tunisian arid regions, plant life forms, ecotypes, physiological types and photosynthetic pathways $\left(C_{3}, C_{4}\right.$ or CAM) remain unclear. Understanding the characters of these plant species could be important for land restoration. A literature survey was conducted for 105 plants species in arid regions of Tunisia. These plant species belong to several ecotypes: halophytes, xerophytes, gypsophytes, psamophytes, xero-halophytes, gypso-halophytes, psamo-halophytes, psamo-xerophytes, xero-gypsophytes and hygro-halophytes. The variation of photosynthetic pathway types in the 105 studied species shows that $56.2 \%$ were $\mathrm{C}_{3}, 41.0 \%$ were $\mathrm{C}_{4}, 1.9 \%$ were $\mathrm{CAM}$ and $1.0 \%$ were $\mathrm{C}_{3}$-CAM. The $\mathrm{C}_{3}$ pathway was more abundant in the halophytes, whereas the $\mathrm{C}_{4}$ one was more common in the xerophytes, gypsophytes, gypso-halophytes and psamo-halophytes. The ratio of $C_{3}$ to $C_{4}$ species $\left(C_{3} / C_{4}\right.$ ratio) was 0.2 in the psamo-halophytes, 0.8 in the gypso-halophytes, 1.1 in the xerophytes, 1.6 in the xero-halophytes, 1.8 in the hygrohalophytes, 2.0 in the psamophytes and 3.8 in the halophytes. The annuals were mainly $C_{3}$ plants whereas most of perennials were $C_{4}$ ones. The $C_{3} / C_{4}$ ratio was 1.3 in succulent species and 1.4 in non-succulent species. Thus, succulence seems not to affect the distribution of $\mathrm{C}_{3}$ and $\mathrm{C}_{4}$ pathways within the studied plants. This investigation shows high percentages of $\mathrm{C}_{4}$ plants occurred in Tunisian arid regions. However, there were significant differences in their abundance among ecotypes. Basing on $\mathrm{C}_{3} / \mathrm{C}_{4}$ ratio, we can find that the abundance of the $\mathrm{C}_{4}$ pathway was in the following order: psamo-halophytes, gypso-halophytes, xerophytes, xero-halophytes, hygro-halophytes, psamophytes and halophytes. In Tunisian arid regions, $\mathrm{C}_{4} \mathrm{species}$ were most abundant in xerophytes and less abundant in halophytes. In the Chenopodiaceae the number of $\mathrm{C}_{3}$ plants was 13 and the number of $C_{4}$ species was 20 and in the Poaceae the number of $C_{3}$ was 23 and the number of $C_{4}$ was 19 species. Thus, the most $\mathrm{C}_{4}$ proportion was in the Chenopodiaceae and Poaceae species. This confirms the fact that the Chenopodiaceae and the Poaceae were the leading families that tolerate salinity and aridity.
\end{abstract}

Keywords: $\mathrm{C}_{3} ; \mathrm{C}_{4}$; CAM; life form; ecotype; physiological type; Tunisian arid regions

Citation: Abdallah ATIA, Mokded RABHI, Ahmed DEBEZ, Chedly ABDELLY, Houda GOUIA, Chiraz Chaffei HAOUARI, Abderrazak SMAOUI. 2014. Ecophysiological aspects and photosynthetic pathways in 105 plants species in saline and arid environments of Tunisia. Journal of Arid Land, 6(6): 762-770. doi: 10.1007/s40333-014-0028-2

In arid and saline regions, plants develop different forms of photosynthetic pathways to cope with the extreme conditions. There are three types of photosynthesis on earth, which are $\mathrm{C}_{3}, \mathrm{C}_{4}$ and CAM. The most common and the most primitive is $\mathrm{C}_{3}$ pathway (or Calvin-Benson cycle). The $\mathrm{C}_{4}$ pathway (or Hatch-Slack cycle) is a more evolutionarily recent photosynthetic pathway. The third one is the crassulacean acid metabolism (CAM). The majority of terrestrial plant species (about 95\%) use the $\mathrm{C}_{3}$ photosynthetic pathway (Osborne and Freckleton, 2009). And only $5 \%$ of species have $\mathrm{C}_{4}$ or CAM photosynthetic pathways. However, $\mathrm{C}_{4}$ photosynthetic pathway accounts for approximately $18 \%$ of the total global

*Corresponding author: Abdallah ATIA (E-mail: atbdllh@yahoo.fr)

Received 2013-09-13, revised 2014-02-12, accepted 2014-03-12

(C) Xinjiang Institute of Ecology and Geography, Chinese Academy of Sciences, Science Press and Springer-Verlag Berlin Heidelberg 2014 
photoproductivity (Ehleringer et al., 1997). In saline and arid areas, the efficiency of $\mathrm{C}_{3}$ photosynthetic pathway is compromised by the increase of photorespiration and its rate is strongly limited by $\mathrm{CO}_{2}$ diffusion from the atmosphere. Under arid climate conditions, photorespiration increases at low $\mathrm{CO}_{2}$ concentrations and high temperatures. The reduction of stomatal aperture decreases $\mathrm{CO}_{2}$ diffusion, which limits photosynthesis activity (Osborne and Freckleton, 2009). $C_{4}$ photosynthetic pathway draws mesophyll $\mathrm{CO}_{2}$ down to lower concentrations than that $\mathrm{C}_{3}$ pathway. It also allows stomatal conductance to be reduced, leading to greater water use efficiency under the same environmental conditions (Downes, 1969). In addition, $\mathrm{C}_{4}$ photosynthetic pathway has the potential to achieve higher rates of photosynthesis than that $\mathrm{C}_{3}$ pathway. It also maximizes dry matter production in water shortage conditions (Osborne and Freckleton, 2009). The mechanism should therefore confer significant selective and competitive benefits for $\mathrm{C}_{4}$ plants over $\mathrm{C}_{3}$ species in arid climates. CAM plants were shown to be the least abundant. In these species, $\mathrm{CO}_{2}$ uptake occurs at night, when stomata open. They typically grow in semi-arid regions, where water deficit is frequent. Indeed, it is widely accepted that CAM photosynthetic pathway is an adaptive mechanism which optimizes water use under conditions of deficient water supply (Herrera, 2009).

It is well known that saline and arid environments are characterized by specific vegetation mainly composed of halophytes, xerophytes, gypsophytes, xerohalophytes, gypso-halophytes and psamo-halophytes. They exhibit morphological and physiological adaptations that allow them to accomplish their life cycle in these environments (Atia et al., 2011). For instance, xerophytes are characterized by a low area/volume ratio and a high palisade tissue/spongy tissue ratio (Wang et al., 2004). Additionally, xerophytes have few relatively large stomata, a thick cuticle, a well-developed water storing tissue, dense epidermal hairs and well-developed water transporting tissues. These adaptations reduce transpiration rate (Wang et al., 2004). Two main groups of halophytes can be distinguished according to their tolerance mechanisms: excluders and includers (Koyro et al., 2008). Excluders minimize ion toxicity and nutritional imbalances by salt exclusion, i.e. avoiding toxic ions by secreting them via salt glands. They are mainly subject to osmotic stress and are non-succulent halophytes. In contrast, includers reduce water deficit by loading toxic ions in vacuoles. They are mainly subject to ion toxicity and nutritional imbalances. The latter two factors can be counteracted, e.g. by salt restriction in the vacuole or by re-translocation via phloem. The osmotic balance between the cell compartments and organs is maintained by the accumulation of compatible organic solutes, such as proline, glycine-betaine and inorganic solutes such as potassium in the cytoplasm (Hafsi et al., 2010). The includers are generally known as succulent halophytes. These mechanisms permit halophytes to survive in extreme environments. Thus, both xerophytes and halophytes have the highest water holding capacities.

However, in Tunisian arid regions, the relationships among plant life form, ecotype, physiological type and photosynthetic pathway remain unclear, and these data are important for land restoration.

This study aims to (1) present an overview about the photosynthetic pathways of arid vegetation in Tunisian and (2) determine the distribution of photosynthetic pathways $\left(\mathrm{C}_{3}, \mathrm{C}_{4}\right.$ and $\left.\mathrm{CAM}\right)$ within plant ecotypes, physiological types and life forms in arid environments in Tunisia.

\section{Study area and methods}

\subsection{Study area}

In Tunisia, $65 \%$ of the terrestrial surface is arid. In these regions, climatic and soil conditions are commonly harsh and unfavourable for plant growth as a result of high evaporation, limited water supply and nutrient availability, low soil organic matter content and high salinity. The climate is characterized by an extreme spatiotemporal irregularity of precipitations. In these areas, the annual precipitation is lower than $300 \mathrm{~mm}$ and erosion is intensive. The highest evaporation in these regions is varied between $900-1,200$ $\mathrm{mm} / \mathrm{a}$ while the annual average temperature is $18-21^{\circ} \mathrm{C}$. The maximum daily temperature reached $55^{\circ} \mathrm{C}$. Furthermore, the increase of anthropogenic disturbances contributes to desertification. For instance, the clear-cutting of native vegetation and the replacement cropland has led to underground water table rising thereby enhancing soil evaporation and salt depo- 
sition.

In Tunisia, the flora of arid regions groups about 1,630 species (Chaieb and Boukhris, 1998) essentially composed of therophytes (43\%), chamephytes (30\%) and hemicryptophytes (20\%). Geophytes and phanerophytes are less abundant, which represent only $4 \%$ and $2 \%$ of total species, respectively. However, there are a few data about the ecophysiological aspects and photosynthetic pathways of these floras in Tunisia. It is well known that high light intensity, high temperature and frequent water shortage are common characters of arid regions. These conditions favour the presence of the $\mathrm{C}_{4}$ plants.

\subsection{Methods}

A literature survey study was conducted. Information regarding species, life form, ecotype, and physiological type (succulent or no-succulent) were obtained from the following references: Flora of Tunisia (Cuénad et al., 1954; Pottier-Alapetite, 1979; 1981) and Flora Succinct and Illustrated of Arid Zones of Tunisia (Chaieb and Boukhris, 1998). Some were from internet sites: www.efloras.org and an official site of the Botanical Society of French: www.bium.parisdescartes. $\mathrm{fr} / \mathrm{sbf} /$. The photosynthetic pathways were determined by using the following references: Winter (1981), Ziegler et al. (1981); Collins and Jones (1985), Batanouny et al. (1988), Akhani et al. (1997) and Yensen database (http://www.ussl.ars.usda.gov/pls/caliche/ halophyte.query.). In this work the studied ecotypes, halophytes, xerophytes, gypsophytes, psamophytes, xero-halophytes, gypso-halophytes, psamo-halophytes, psamo-xerophytes, xero-gypsophytes and hygrohalophytes were commonly found in arid and saline zones (Chaieb and Boukhris, 1998; Alegro et al., 2004; Khadri et al., 2013).

\section{Results}

Out of the 105 studied species, the percentage of five ecotypes was higher than $10 \%$ for halophytes, xerophytes, xero-halophytes, psamo-halophytes and hygro-halophytes (Table 1; Fig. 1). The analysis of the photosynthetic pathway in the 105 studied species showed that $56.2 \%$ were $\mathrm{C}_{3}, 41.0 \%$ were $\mathrm{C}_{4}, 1.9 \%$ were $\mathrm{CAM}$ and $1.0 \%$ were $\mathrm{C}_{3}$-CAM (Table 1 ). Thus, the $\mathrm{C}_{4}$ form is highly represented in all studied ecotypes. In the halophyte, the species with $\mathrm{C}_{4}$ form were less abundant in comparison to the abundance in the other ecotypes (Fig. 2). In this ecotype the $\mathrm{C}_{3} / \mathrm{C}_{4}$ ratio was 3.8 (Fig. 3). However, in the xerophytes the $\mathrm{C}_{4}$ form was more abundant (Fig. 2). The $\mathrm{C}_{3} / \mathrm{C}_{4}$ ratio was 1.12 (Fig. 3). Surprisingly, all gypsophytes were $\mathrm{C}_{4}$ (Fig. 2). A percentage of $2.9 \%$ of the studied species were psamophytes, of which $34.4 \%$ were $\mathrm{C}_{4}$ types (Fig. 2). In these species, the $C_{3} / C_{4}$ ratio is 2.0 (Fig. 3). The

Table 1 Species, photosynthetic pathway, ecotype, succulence and life form

\begin{tabular}{|c|c|c|c|c|}
\hline Species & $\mathrm{C}_{3} / \mathrm{C}_{4}$ & Ecotype & Succulence & Life form \\
\hline \multicolumn{5}{|l|}{ Aizoaceae } \\
\hline Aizoon canariense & $\mathrm{C}_{3}$ & Hal & Succulent & Annual \\
\hline Mesembryanthemum cristallinum & $\mathrm{C}_{3}$-CAM & Hal & Succulent & Annual \\
\hline Mesembryanthemum nodiflorum & CAM & Hal & Succulent & Annual \\
\hline \multicolumn{5}{|l|}{ Apiaceae } \\
\hline Crithmum maritimum & $\mathrm{C}_{3}$ & Hal & Succulent & Perennial \\
\hline \multicolumn{5}{|l|}{ Asteraceae } \\
\hline Inula crithmoides & $\mathrm{C}_{3}$ & Hyg-hal & Succulent & Perennial \\
\hline \multicolumn{5}{|l|}{ Brassicaceae } \\
\hline Cakile maritima & $\mathrm{C}_{3}$ & Hal & Succulent & Annual \\
\hline \multicolumn{5}{|l|}{ Boraginacae } \\
\hline Heliotropium curassavicum & $\mathrm{C}_{4}$ & Hal & Succulent & Perennial \\
\hline \multicolumn{5}{|l|}{ Cactaceae } \\
\hline Opuntia ficus-barbarica & CAM & Xer & Succulent & Perennial \\
\hline \multicolumn{5}{|l|}{ Chenopodiaceae } \\
\hline Anabasis aphylla & $\mathrm{C}_{4}$ & Psam-hal & Succulent & Perennial \\
\hline Anabasis oropediorum & $\mathrm{C}_{4}$ & Hal & Succulent & Perennial \\
\hline
\end{tabular}


Continue

\begin{tabular}{|c|c|c|c|c|}
\hline Species & $\mathrm{C}_{3} / \mathrm{C}_{4}$ & Ecotype & Succulence & Life form \\
\hline Arthrocnemum macrostachyum & $\mathrm{C}_{3}$ & Hal & Succulent & Perennial \\
\hline Atriplex coriacea & $\mathrm{C}_{4}$ & Psam-hal & Non-succulent & Perennial \\
\hline Atriplex dimorphostegia & $\mathrm{C}_{4}$ & Xer & Non-succulent & Annual \\
\hline Atriplex glauca & $\mathrm{C}_{4}$ & Hal & Non-succulent & Perennial \\
\hline Atriplex halimus & $\mathrm{C}_{4}$ & Xer-hal & Non-succulent & Perennial \\
\hline Atriplex mollis & $\mathrm{C}_{3}$ & Xer-hal & Non-succulent & Perennial \\
\hline Atriplex tatarica & $\mathrm{C}_{4}$ & Gyp-hal & Non-succulent & Perennial \\
\hline Atriplex portulacoides & $\mathrm{C}_{3}$ & Hal & Non-succulent & Perennial \\
\hline Atriplex hastata & $\mathrm{C}_{3}$ & Hal & Non-succulent & Perennial \\
\hline Bassia indica & $\mathrm{C}_{4}$ & Hal & Non-succulent & Annual \\
\hline Beta maritima & $\mathrm{C}_{3}$ & Hal & Succulent & Annual \\
\hline Chenopodium ambrosoides & $\mathrm{C}_{3}$ & Hal & Succulent & Annual \\
\hline Cornulaca monacantha & $\mathrm{C}_{4}$ & Xer-hal & Succulent & Annual \\
\hline Halocnemum strobilaceum & $\mathrm{C}_{3}$ & Hal & Succulent & Perennial \\
\hline Halopeplis amplexicaulis & $\mathrm{C}_{3}$ & Hyg-hal & Non-succulent & Annual \\
\hline Hammada scoparia & $\mathrm{C}_{4}$ & Gyp & Non-succulent & Perennial \\
\hline Salicornia arabica & $\mathrm{C}_{3}$ & Hal & Succulent & Perennial \\
\hline Salicornia europea & $\mathrm{C}_{3}$ & Hal & Succulent & Annual \\
\hline Salsola vermiculata & $\mathrm{C}_{4}$ & Hal & Succulent & Perennial \\
\hline Salsola kali & $\mathrm{C}_{4}$ & Psam-hal & Succulent & Annual \\
\hline Salsola longifolia & $\mathrm{C}_{4}$ & Gyp-Hal & Succulent & Perennial \\
\hline Salsola tetragona & $\mathrm{C}_{4}$ & Xer & Succulent & Perennial \\
\hline Salsola tetandra & $\mathrm{C}_{4}$ & Xer-hal & Succulent & Perennial \\
\hline Salsola sieberi & $\mathrm{C}_{4}$ & Psam-hal & Succulent & Perennial \\
\hline Salsola villosa & $\mathrm{C}_{4}$ & Psam-hal & Succulent & Perennial \\
\hline Suaeda maritima & $\mathrm{C}_{3}$ & Hal & Succulent & Annual \\
\hline Suaeda fruticosa var. langifolia & $\mathrm{C}_{3}$ & Hal & Succulent & Perennial \\
\hline Suaeda fruticosa var. brevifolia & $\mathrm{C}_{3}$ & Hal & Succulent & Perennial \\
\hline Suaeda vermiculata & $\mathrm{C}_{4}$ & Hal & Succulent & Perennial \\
\hline Traganum nudatum var. abtusatum & $\mathrm{C}_{4}$ & Gyp-Hal & Succulent & Perennial \\
\hline Traganum nudatum var. microphyllum & $\mathrm{C}_{4}$ & Gyp-Hal & Succulent & Perennial \\
\hline \multicolumn{5}{|l|}{ Cypreceae } \\
\hline Cyperus capitatus & $\mathrm{C}_{4}$ & Hyg-hal & Non-succulent & Perennial \\
\hline \multicolumn{5}{|l|}{ Frankeniaceae } \\
\hline Frankenia pulverulenta & $\mathrm{C}_{3}$ & Hal & Succulent & Annual \\
\hline \multicolumn{5}{|l|}{ Juncaceae } \\
\hline Juncus maritimus var. typicus & $\mathrm{C}_{3}$ & Hyg-hal & Non-succulent & Perennial \\
\hline Juncus maritimus var. arabicus & $\mathrm{C}_{3}$ & Hyg-hal & Non-succulent & Perennial \\
\hline Juncus acutus & $\mathrm{C}_{3}$ & Hyg-hal & Non-succulent & Perennial \\
\hline \multicolumn{5}{|l|}{ Poaceae } \\
\hline Aegylops geniculata & $\mathrm{C}_{3}$ & Xer & Non-succulent & Annual \\
\hline Aeluropus littorlis var. intermedius & $\mathrm{C}_{4}$ & Gyp-hal & Non-succulent & Perennial \\
\hline Aristida coerulescens & $\mathrm{C}_{4}$ & Psam-hal & Non-succulent & Perennial \\
\hline Bromus madritensis & $\mathrm{C}_{3}$ & Xer & Non-succulent & Annual \\
\hline Catapodium regidum & $\mathrm{C}_{3}$ & Hal & Non-succulent & Annual \\
\hline Cenchrus ciliaris & $\mathrm{C}_{4}$ & Xer & Non-succulent & Perennial \\
\hline Crypsis aculeata & $\mathrm{C}_{4}$ & Hyg-hal & Non-succulent & Annual \\
\hline Cutandia dichotoma & $\mathrm{C}_{3}$ & Xer & Non-succulent & Annual \\
\hline
\end{tabular}


Continue

\begin{tabular}{|c|c|c|c|c|}
\hline Species & $\mathrm{C}_{3} / \mathrm{C}_{4}$ & Ecotype & Succulence & Life form \\
\hline Cutandia maritima & $\mathrm{C}_{3}$ & Psam-hal & Non-succulent & Annual \\
\hline Cutandia philistaea & $\mathrm{C}_{3}$ & Psam-xer & Non-succulent & Annual \\
\hline Cymbopogon schoenanthus & $\mathrm{C}_{4}$ & Xer-hal & Non-succulent & Perennial \\
\hline Cynodon dactylon & $\mathrm{C}_{4}$ & Xer-hal & Non-succulent & Perennial \\
\hline Dactylis glomerata var. hispanica & $\mathrm{C}_{3}$ & Xer & Non-succulent & Perennial \\
\hline Dactylis glomerata var. maritima & $\mathrm{C}_{3}$ & Xer-hal & Non-succulent & Perennial \\
\hline Digitaria nodosa & $\mathrm{C}_{4}$ & Xer & Non-succulent & Perennial \\
\hline Eragrostis barrelieris & $\mathrm{C}_{4}$ & Psam & Non-succulent & Annual \\
\hline Hordeum marinum & $\mathrm{C}_{3}$ & Hal & Non-succulent & Annual \\
\hline Cutandia philistaea & $\mathrm{C}_{3}$ & Psam-xer & Non-succulent & Annual \\
\hline Hypparrhenia hirta & $\mathrm{C}_{4}$ & Xer & Non-succulent & Perennial \\
\hline Imperata cylindrica & $\mathrm{C}_{4}$ & Psam-hal & Non-succulent & Perennial \\
\hline Koeleria pubscens & $\mathrm{C}_{3}$ & Xer & Non-succulent & Annual \\
\hline Lagurus ovatus & $\mathrm{C}_{3}$ & Xer-hal & Non-succulent & Annual \\
\hline Lamarckia aurea & $\mathrm{C}_{3}$ & Hal & Non-succulent & Annual \\
\hline Lolium rigidum & $\mathrm{C}_{3}$ & Psam & Non-succulent & Annual \\
\hline Lygeum spartum & $\mathrm{C}_{3}$ & Xer-gyp & Non-succulent & Perennial \\
\hline Oryzopsis miliacea & $\mathrm{C}_{3}$ & Xer & Non-succulent & Perennial \\
\hline Panicum turgidum & $\mathrm{C}_{4}$ & Psam-hal & Non-succulent & Perennial \\
\hline Panicum repens & $\mathrm{C}_{4}$ & Hyg-hal & Non-succulent & Perennial \\
\hline Pennisetum setaceum & $\mathrm{C}_{4}$ & Xer & Non-succulent & Perennial \\
\hline Polypogon monspelensis & $\mathrm{C}_{3}$ & Hyg-hal & Non-succulent & Annual \\
\hline Schismus barbatus & $\mathrm{C}_{3}$ & Psam & Non-succulent & Annual \\
\hline Spartina patens & $\mathrm{C}_{4}$ & Hyg-hal & Non-succulent & Perennial \\
\hline Sporobolus pungens & $\mathrm{C}_{4}$ & Psam-hal & Non-succulent & Perennial \\
\hline Sphenopus divaricatus & $\mathrm{C}_{3}$ & Hal & Non-succulent & Annual \\
\hline Sphenopus syrticus & $\mathrm{C}_{3}$ & Hyg-hal & Non-succulent & Annual \\
\hline Stipa capensis & $\mathrm{C}_{3}$ & Xer & Non-succulent & Annual \\
\hline Stipa lagascae & $\mathrm{C}_{3}$ & Xer & Non-succulent & Perennial \\
\hline Stipa parviflora & $\mathrm{C}_{3}$ & Gyp-hal & Non-succulent & Perennial \\
\hline Stipa tenacissima & $\mathrm{C}_{3}$ & Xer & Non-succulent & Perennial \\
\hline Stipagrostis ciliata & $\mathrm{C}_{4}$ & Gyp & Non-succulent & Perennial \\
\hline Stipagrostis obtusa & $\mathrm{C}_{4}$ & Xer & Non-succulent & Perennial \\
\hline Stipagrostis plumosa & $\mathrm{C}_{4}$ & Xer & Non-succulent & Perennial \\
\hline Stipagrostis pungens & $\mathrm{C}_{4}$ & Psam-xer & Non-succulent & Perennial \\
\hline \multicolumn{5}{|l|}{ Plumbaginaceae } \\
\hline Limoniastrum monopetalum & $\mathrm{C}_{3}$ & Gyp-hal & Non-succulent & Perennial \\
\hline Limonium sinuatum ssp. eu-sinuatum & $\mathrm{C}_{3}$ & Psam-hal & Non-succulent & Perennial \\
\hline Limonium sinuatum ssp. bonuelli & $\mathrm{C}_{3}$ & Xer-hal & Non-succulent & Annual \\
\hline \multicolumn{5}{|l|}{ Plantaginaceae } \\
\hline Plantago coronopus & $\mathrm{C}_{3}$ & Hal & Succulent & Annual \\
\hline Plantago crassifolia & $\mathrm{C}_{3}$ & Hyg-hal & Succulent & Perennial \\
\hline \multicolumn{5}{|l|}{ Polygonaceae } \\
\hline Polygonum patulum & $\mathrm{C}_{4}$ & Psam-hal & Non-succulent & Annual \\
\hline \multicolumn{5}{|l|}{ Portulacaceae } \\
\hline Portulaca oleracea $\mathrm{L}$. & $\mathrm{C}_{4}$ & Hyg-hal & Succulent & Annual \\
\hline \multicolumn{5}{|l|}{ Primulaceae } \\
\hline Anagallis arvensis & $\mathrm{C}_{3}$ & Xer-hal & Non-succulent & Annual \\
\hline
\end{tabular}

To be continued 
Continue

\begin{tabular}{|c|c|c|c|c|}
\hline \multicolumn{5}{|l|}{ Tamaricaceae } \\
\hline Tamarix africana & $\mathrm{C}_{3}$ & Xer-hal & Non-succulent & Perennial \\
\hline Tamarix aphylla & $\mathrm{C}_{3}$ & Xer-hal & Non-succulent & Perennial \\
\hline Tamarix gallica ssp. nilotica & $\mathrm{C}_{3}$ & Xer-hal & Non-succulent & Perennial \\
\hline Tamarix gallica ssp. gallica & $\mathrm{C}_{3}$ & Hal & Non-succulent & Perennial \\
\hline Tamarix boveana & $\mathrm{C}_{3}$ & Hyg-hal & Non-succulent & Perennial \\
\hline \multicolumn{5}{|l|}{ Zygophyllaceae } \\
\hline Nitraria retusa & $\mathrm{C}_{3}$ & Gyp-hal & Succulent & Perennial \\
\hline Peganum harmala & $\mathrm{C}_{3}$ & Hal & Succulent & Annual \\
\hline Zygophyllum album ssp. album & $\mathrm{C}_{3}$ & Gyp-hal & Succulent & Annual \\
\hline Zygophyllum album ssp. geslini & $\mathrm{C}_{3}$ & Hal & Succulent & Annual \\
\hline
\end{tabular}

Note: Hal, Halophyte; Xer, Xerophytes; Xer-hal, Xero-halophytes (desert species suspected as halophytes). Gyp, Gypsophytes; Psam, Psamophyte; Psam-hal, Psamo-halophytes; Gyp-Hal, Gypso-halophytes; Xero-gyp, Xero-gypsophytes; Psam-xer, Psamo-xerophytes.

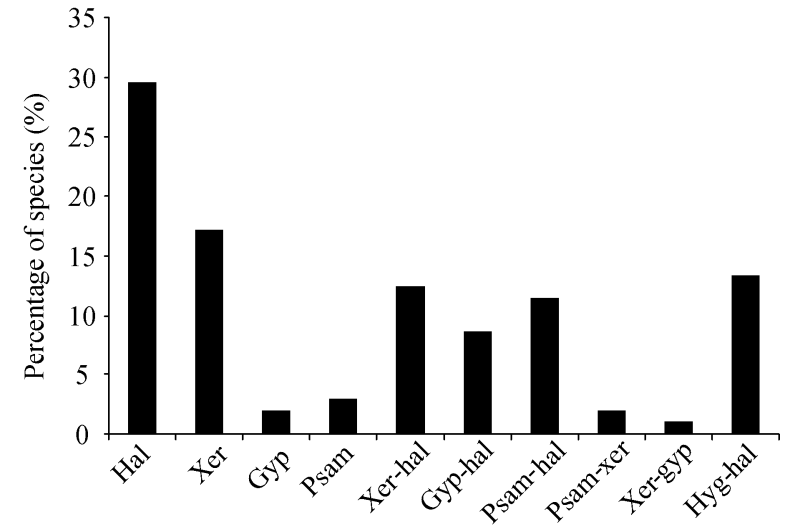

Fig. 1 Percentage of different ecotypes in the studied species. Hal, Halophyte; Xer, Xerophytes; Xer-hal, Xero-halophytes (desert species suspected as halophytes). Gyp, gypsophytes; Psam, Psamophyte; Psam-hal, Psamo-halophytes; Gyp-Hal, Gypso- halophytes; Xero-gyp, Xero-gypsophytes; Psam-xer, Psamo- xerophytes. Symbols are the same as in Figs. 2 and 3.

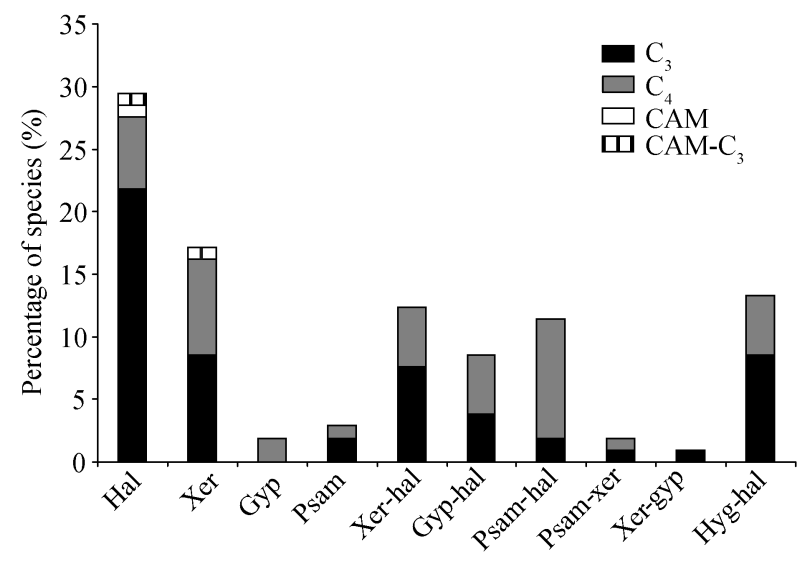

Fig. 2 Variations of photosynthetic pathway in different ecotypes

xero-halophytes represent $12.4 \%$ of the studied species, $4.8 \%$ of them were $\mathrm{C}_{4}$ (Fig. 2). Their $\mathrm{C}_{3} / \mathrm{C}_{4}$ ratio is 1.6 (Fig. 3). In the gypso-halophytes the dom- inant form was $\mathrm{C}_{4}$ (Fig. 2). The percentage of $\mathrm{C}_{4}$ psamo-halophytes species reached $9.5 \%$ (Fig. 2). In these species, the $\mathrm{C}_{3} / \mathrm{C}_{4}$ ratio was 0.2 (Fig. 3). The percentage of the psamo-xerophytes was about $2 \%$ and the $\mathrm{C}_{3} / \mathrm{C}_{4}$ ratio was about 1 (Fig. 2). The xero-gypsophytes was represented by 1 species and had $\mathrm{C}_{3}$ photosynthetic pathway (Fig. 2). The percentage of hygro-halophytes was $13.2 \%$ and $4.8 \%$ of them was $\mathrm{C}_{4}$ (Fig. 2). And their $\mathrm{C}_{3} / \mathrm{C}_{4}$ ratio was 1.8 (Fig. 3). As concerns physiological type, there were two types in the 105 studied species: 38 species were succulent and 67 species were non-succulent (Table 1). Among the succulent species, $19.0 \%$ were $\mathrm{C}_{3}, 14.3 \%$ were $\mathrm{C}_{4}, 1.9 \%$ were $\mathrm{CAM}$ and $1.0 \%$ were $\mathrm{C}_{3}$-CAM (Fig. 4). Among the non-succulent species, there were $37.1 \% \mathrm{C}_{3}$ and $26.7 \% \mathrm{C}_{4}$ (Fig. 4). The $\mathrm{C}_{3} / \mathrm{C}_{4}$ ratio is 1.3 and 1.4 respectively for succulent and non-succulent species (Fig. 6a). Of the studied vegetation, there were 40

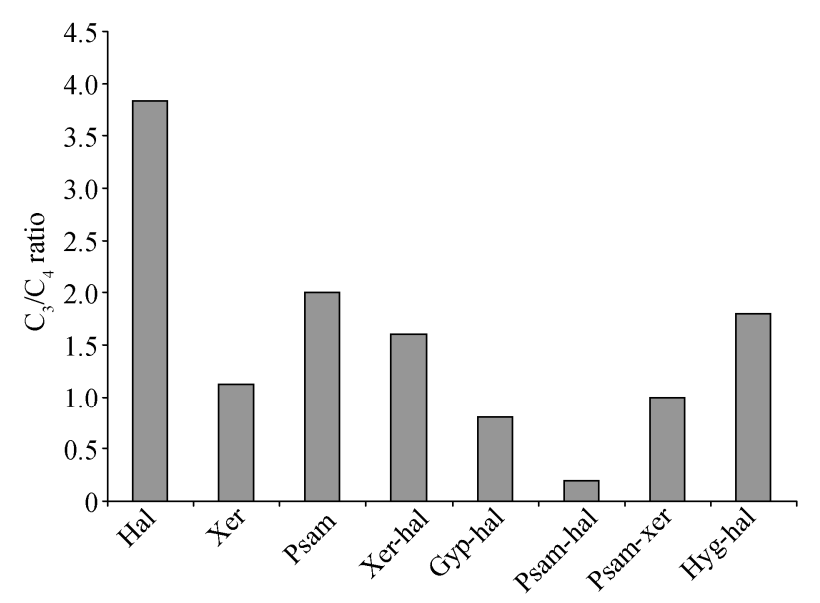

Fig. 3 Composition of different photosynthetic pathways $\left(\mathrm{C}_{3} / \mathrm{C}_{4}\right.$ ratio $)$ in different ecotypes 


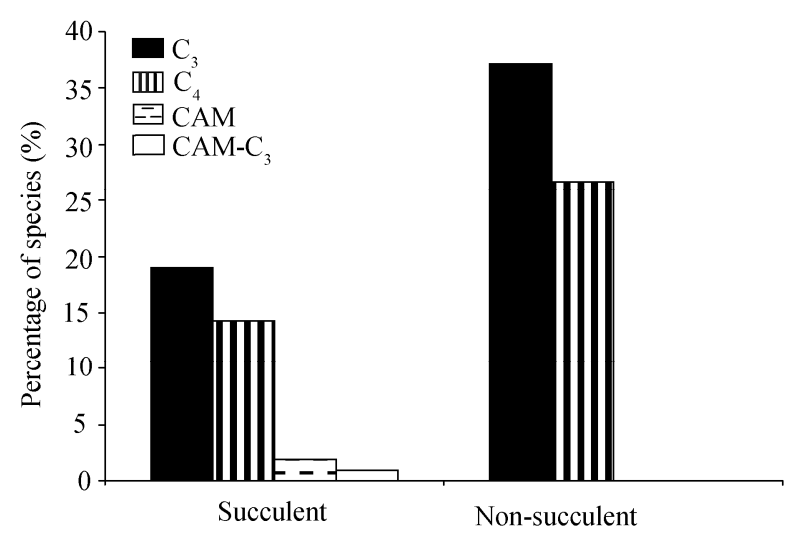

Fig. 4 Variations of photosynthetic pathway between succulent and non-succulent species

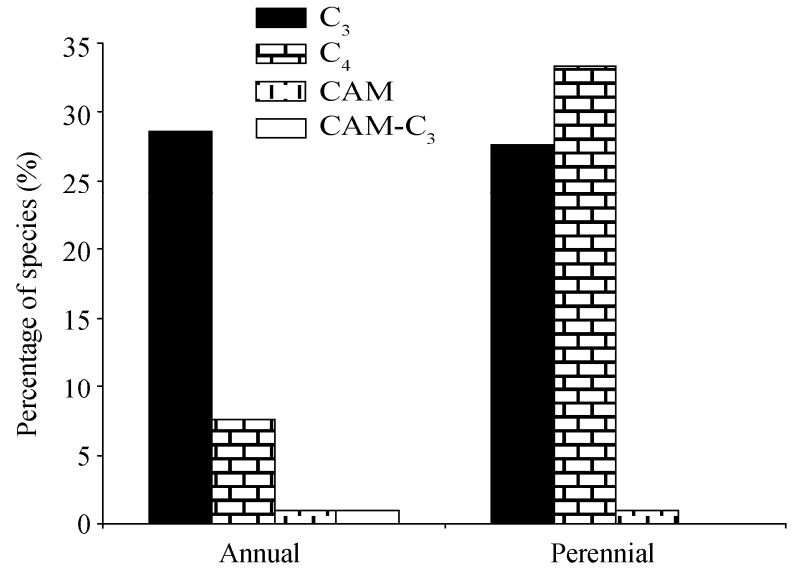

Fig. 5 Photosynthetic pathways variation between annual and perennial species

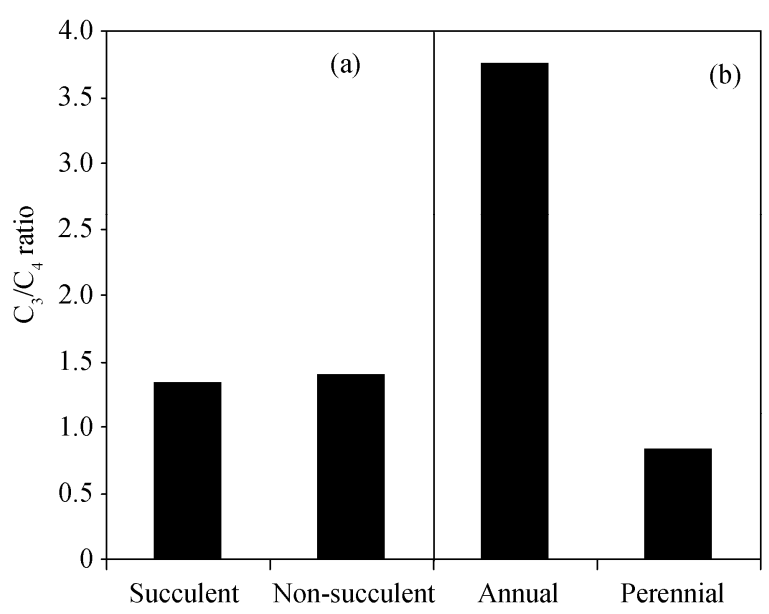

Fig. 6 Variations of $\mathrm{C}_{3} / \mathrm{C}_{4}$ ratio between succulent and non-succulent species (a) and between annual and perennial species (b)

annual and 65 perennial species (Table 1). Among the annual species, $28.6 \%$ were $\mathrm{C}_{3}, 7.6 \%$ were $\mathrm{C}_{4}$,
$1.0 \%$ were $\mathrm{CAM}$ and $1.0 \%$ were $\mathrm{C}_{3}$-CAM. As regards the perennial species, $27.6 \%$ were $\mathrm{C}_{3}, 33.3 \%$ were $\mathrm{C}_{4}$ and $1.0 \%$ were CAM (Fig. 5). The $\mathrm{C}_{3} / \mathrm{C}_{4}$ ratio was 3.8 and 0.8 for the annual and perennial species, respectively (Fig. 6b).

\section{Discussion and conclusion}

In this paper, the studied species were classified according to their life forms (annual or perennial), physiological types (succulent or non-succulent) and photosynthetic pathways $\left(\mathrm{C}_{3}, \mathrm{C}_{4}\right.$ or $\left.\mathrm{CAM}\right)$. However, the classification of plant species on the basis of photosynthetic pathways is the fundamental knowledge for a true understanding of the differences in ecophysiological responses among plants (Wang, 2007).

Terrestrial vegetation is composed of about $95 \%$ $\mathrm{C}_{3}$ plants and only about $5 \% \mathrm{C}_{4}$ plants (Warrick et al., 1986). Thus, for total world vegetation, the $C_{3} / C_{4}$ ratio is about 19. This paper showed that there was an abundance of the $\mathrm{C}_{4}$ group in the arid regions of Tunisia. This is a common property in all arid zones throughout the world. However, the composition of photosynthetic pathways differs greatly among ecotypes, life forms and physiological types (succulent and non-succulent species).

In the halophyte species, there is more abundance of $\mathrm{C}_{3}$ species in comparison to their abundance in the other ecotypes. Relatively, more $\mathrm{C}_{4}$ species were previously identified in halophytes around the world. For instance, Wang (2007) observed that in 61 halophytes, 18 species were $\mathrm{C}_{4}$ and 43 species were $\mathrm{C}_{3}$. However, in northeastern China, the number of $\mathrm{C}_{4}$ species in saline grasslands was higher than in the other areas (Wang, 2002). The abundance of $\mathrm{C}_{4}$ species was very common in saline regions because they had relative higher saline tolerance and water use efficiency (Wang, 2004).

In the xerophyte species, the $\mathrm{C}_{3} / \mathrm{C}_{4}$ ratio was 1.1 . This ratio is very low when compared to $\mathrm{C}_{3} / \mathrm{C}_{4}$ world ratio. Thus, the dominance of $\mathrm{C}_{4}$ plants among the xerophytes is evident. Our results are consistent with previous researches conducted in other arid areas in the world such as Xilingol steppes and Hunshandake Desert in China (Wang, 2002). This was mainly due to greater ability of $\mathrm{C}_{4}$ species to 
maintain high photosynthetic activity during the dry season (Wang, 2004). In arid areas, the efficiency of $\mathrm{C}_{3}$ photosynthetic pathway is influenced by the increase of photorespiration and its rate is strongly limited by $\mathrm{CO}_{2}$ diffusion from stomata. However, $\mathrm{C}_{4}$ photosynthesis minimises mesophyll $\mathrm{CO}_{2}$ and reduces stomatal conductance for higher water-use efficiency than that of $C_{3}$ pathway under the same environmental conditions (Osborne and Freckleton, 2009).

In the xero-halophytes, the $\mathrm{C}_{3} / \mathrm{C}_{4}$ ratio was 1.6 . Thus, the $\mathrm{C}_{4}$ photosynthetic pathway was also abundant in the xero-halophytes. This is mainly due to the high tolerance of $\mathrm{C}_{4}$ species to environmental stresses and the great ability to maintain high photosynthesis activity under harsh environment, e.g. drought and salinity (Wang, 2004). In the psamophytes, the $\mathrm{C}_{3} / \mathrm{C}_{4}$ ratio was 2.0 . However, in the psamo-halophytes, there was a higher proportion of $\mathrm{C}_{4}$ species, the $\mathrm{C}_{3} / \mathrm{C}_{4}$ ratio being 0.2 . Indeed, these species are subjected to extreme conditions like sandy soil, e.g. fixed dunes and mobile dunes, salinity, low moisture conditions and low nutrient availability. These plants can be used for the vegetation recovery in arid areas in Tunisia. The occurrence of the hygro-halophytes under the arid climate was observed near the littoral zones and in salty marshes. In these conditions, plants are subjected to anoxia, high salinity and poor nitrogen nutrition (Drake, 1989). These results confirm the fact that $\mathrm{C}_{4}$ is abundant $\left(\mathrm{C}_{3} / \mathrm{C}_{4}\right.$ ratio=1.8) in the extreme conditions. Hence, photosynthetic pathway types, especially the occurrence of $\mathrm{C}_{4}$ species, could be efficient indicators of stress tolerance.

A significant difference is observed between the annual and the perennial species in $\mathrm{C}_{3} / \mathrm{C}_{4}$ ratio. The $\mathrm{C}_{4}$ pathway is more abundant in the perennial species than in the annual species. This is related to the fact that the formers should survive through dry season and consequently they need the $\mathrm{C}_{4}$ photosynthetic pathway to overcome the severe conditions. The higher abundance of the $C_{3}$ pathway in the annual species is due to the fact that they are mainly winter annual species. They achieve their cycle during winter season and evade dry conditions. They go through the severe dry seasons in the form of seed.
In the Chenopodiaceae family, the number of $\mathrm{C}_{3}$ plants is 13 and the number of $\mathrm{C}_{4}$ species is 20 and in the Poaceae family the number of $\mathrm{C}_{3}$ was 23 and the number of $\mathrm{C}_{4}$ was 19 species (Table 1). Thus, the most $\mathrm{C}_{4}$ proportion is in the Chenopodiaceae and Poaceae species. Although the latter species were more abundant, the formers had higher proportion of $\mathrm{C}_{4}$. This confirmed the fact that the Chenopodiaceae (Winter, 1981; Pyankov et al., 2000) and the Poaceae (Wang, 2004) are the leading family that tolerate salinity and aridity and constitute the most abundant species in the studied region.

In conclusion, the $\mathrm{C}_{4}$ photosynthetic pathway was evidently the abundant form in the flora of Tunisian arid regions. Most of $\mathrm{C}_{4}$ species were found in Chenopodiacieae and Poaceae families. However, there are significant differences among ecotypes. According to the $\mathrm{C}_{3} / \mathrm{C}_{4}$ ratio, the abundance of the C4 pathway in Tunisia was in the order of psamo-halophytes $>$ gypso-halophytes $>$ xerophytes $>$ xero-halophytes $>$ hygro-halophytes $>$ psamophytes $>$ halophytes (Fig. 3). The annual species were essentially $\mathrm{C}_{3}$ whereas most perennials are $\mathrm{C}_{4}$ species. For succulent and non-succulent species, $\mathrm{C}_{3}$ and $\mathrm{C}_{4}$ photosynthetic pathways are similar in both physiological types.

\section{References}

Akhani H, Trimborn P, Ziegle H 1997. Photosynthetic pathways in Chenopodiaceae from Africa, Asia and Europe with their ecological, phytogeographical and taxonomical importance. Plant Systematic and Evolution, 206: 187-221.

Alegro A, Biljakovic M, Bogdanovic S, et al. 2004. Psammo-halophytic vegetation on the largest sand area on the Croatian coast: the island of Mljet, southern Adriatic. Biologia, 59: 435-445.

Atia A, Smaoui A, Barhoumi Z, et al. 2011. Differential response to salinity and water deficit stress in Polypogon monspeliensis (L.) Desf. provenances during germination. Plant Biology, 13: $541-545$.

Batanouny K H, Stichler W, Ziegler H. 1988. Photosynthetic pathways, distribution, and ecological characteristics of grass species in Egypt. Oecologia, 75: 539-548.

Chaib M, Boukhris M. 1998. Flora Succinct and Illustrated of Arid Zones of Tunisia. The Association of Nature and Environment of sfax.. Tunisia: Gold Time.

Collins R P, Jones M B. 1985. The influence of climatic factors on the distribution of $\mathrm{C}_{4}$ species in Europe. Vegetatio, 64: 11-129. 
Cuénad A, Pottier-Alapetite G, Labbe A. 1954. Vascular Cryptogams, Gymnosperms and Monocotyledons. Tunisia: Official Printing Office of the Republic the Tunisia.

Downes R W. 1969. Differences in transpiration rates between tropical and temperate grasses under controlled conditions. Planta, 88: 261-273.

Drake B G. 1989. Photosynthesis of salt marsh species. Aquatic Botany, $34: 167-180$.

Ehleringer J R, Cerling T E, Helliker B R. 1997. C 4 photosynthesis, atmospheric $\mathrm{CO}_{2}$, and climate. Oecologia, 112: 285-299.

Hafsi C, Romero-Puertas M C, Gupta D K, et al. 2010. Moderate salinity enhances the antioxidative response in the halophyte Hordeum maritimum L. under potassium deficiency. Environmental and Experimental Botany, 69: 129-136.

Herrera A. 2009. Crassulacean acid metabolism and fitness under water deficit stress: if not for carbon gain, what is facultative CAM good for? Annals of Botany, 103: 645-653.

Khadhri A, Neffati M, Smiti S. 2013. Physiological response of Reaumuria vermiculata to salinity. Acta Botanica Gallica, 158: 291-301. doi:10.1080/12538078.2011.10516274.

Koyro H W, Geibler N, Hussin S, et al. 2008. Survival at extreme locations: life strategies of halophytes-the long way from system ecology, whole plant physiology, cell biochemistry and molecular aspects back to sustainable utilization at field sites. In: Abdelly C, Ashraf M, Oztürk M. Biosaline Agriculture and Salinity Tolerance in Plants. Switzerland: Verlag, 241-246.

Osborne C P, Freckleton R P. 2009. Ecological selection pressures for $\mathrm{C}_{4}$ photosynthesis in the grasses. Proceedings of the Royal Society, Series B, 276: 1753-1760, doi:10.1098/rspb.2008.1762.

Pottier-Alapetite G. 1979. Flora of Tunisia: Angiosperm-dicotyledonous Apetalous-dialipytalous. Tunisia: Official Printing Office of the Republic of Tunisia.
Pottier-Alapetite G. 1981. Flora of Tunisia: Angiosperm- dicotyledonous gamopetalous. Tunisia: Official Printing Office of the Republic of Tunisia.

Pyankov V I, Gunin P D, Tsoog S, et al. 2000. C4 plants in the vegetation of Mongolia: their natural occurrence and geographical distribution in relation to climate. Oecologia, 123: 15-31.

Wang R Z. 2002. Photosynthetic pathways and life forms in different grassland types from North China. Photosynthetica, 40: 243-250.

Wang R Z. 2004. Photosynthetic pathways and life form types for native plant species from Hulunbeier Rangelands, Inner Mongolia, North China. Photosynthetica, 42: 219-227.

Wang R Z. 2005. $C_{3}$ and $C_{4}$ photosynthetic pathways and life form types for native species from agro-forestry region, Northeastern China. Photosynthetica, 43: 535-549.

Wang R Z. 2007. $\delta^{13} \mathrm{C}$ values, photosynthetic pathways, and plant functional types for some plants from saline meadows, Northeastern China. Photosynthetica, 45: 18-22.

Wang S, Wan C, Wang Y, et al. 2004. The characteristics of $\mathrm{Na}^{+}, \mathrm{K}^{+}$ and free proline distribution in several drought-resistant plants of the Alxa Desert, China Journal of Arid Environments, 56: 525-539.

Warrick R, Gifford R, Parry M, 1986. Climate change and agriculture. In: Bolin B. The Greenhouse Effect, Climate Change and Ecosystems. New York: John Wiley, 393-473.

Winter K. 1981. C 4 Plants of high biomass in arid regions of Asia -Occurrence of $\mathrm{C}_{4}$ photosynthesis in chenopodiaceae and polygonaceae from the Middle East and USSR. Oecologia, 48: $100-106$.

Ziegler H, Batanouny K H, Sankhla N, et al. 1981. The photosynthetic pathway types of some desert plants from India, Saudi Arabia, Egypt and Iraq. Oecologia, 48: 93-99. 